\title{
炭酸ストロンチウム投与ラットの血清中における 無機および有機成分の含有量について
}

\author{
松本章 \\ 鶴見大学歯学部 薬理学教室*
}

[受付 : 昭和51年 6 月 24 日]

抄録：炭酸ストロンチウム投与ラットに打いては歯，骨，軟骨などの硬組織に形成障害の発現することが 知られている。本実験はこの場合の, ラットの血清中における $\mathrm{Ca}, \mathrm{P}, \mathrm{Sr}, \mathrm{Mg}$ などの無機成分ならびに総 ヘキソサミン，八イドロキシプロリンなどの含有量を測定したものである。Sr 投与ラットの血清中では，

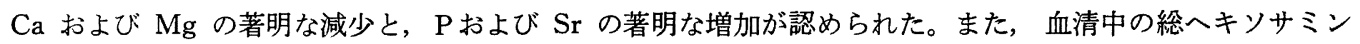
および八イドロキシプロリンも著しい増加を示した。Sr と Ca を併用した場合には血中無機および有機成 分の変動は，Sr を単独投与した場合とほぼ同じ傾向を示したが，その程度はそれほど著しくはなかった。 Sr 投与により, 多糖類代謝やコラーゲン代謝が阻害され, それに伴って硬組織形成障害の発現することが示 唆される。

\section{緒言}

ストロンチウム塩 $(\mathrm{Sr}$ 塩)を動物へ投与すると硬 組織の発育障害が発現することは周知の 事実であ $ろ^{1-5)}$ 。この場合の硬組織中の 無機成分, 有機成 分の含有量の変動についてはすでに 報告されてい $ろ^{6-8)}$ 。

$\mathrm{Sr}$ 塩投与動物 の 血清中における 無機成分含有 量の変化については，当然のことながら $\mathrm{Sr}$ 投与 量に比例して Sr 含有量が増加するが，これに対 して $\mathrm{Ca}$ ，含有量は減少を示すことが報告されて いる ${ }^{9-12)}$ 。しかし血清中の有機成分の含有量の変 化については，殆んど知られていない。

そこで本実験においては炭酸ストロンチウム投 与ラットの血清中における $\mathrm{Ca}, \mathrm{P}, \mathrm{Sr}, \mathrm{Mg}$ など の無機成分抒よび総ヘキソサミン，ハイドロキシ プロリンなどの有機成分の含有量を測定した。

\section{材料ならびに方法}

体重 $50 \mathrm{~g}$ 前後のウィスター系雄性ラット40匹を 10匹ずつの 4 群に分け，それぞれ正常配合飼料
(対照群)，低カルシウム飼料（低 $\mathrm{Ca}$ 群)，スト ロンチウム飼料 ${ }^{13)}$ ( $\mathrm{Sr}$ 群)， ストロンチウム・カ ルシウム飼料（Sr-Ca 群）で 4 週間飼育した。Sr$\mathrm{Ca}$ 飼料の主な成分は, $\mathrm{CaCO}_{3} 1.5 \% ; \mathrm{SrCO}_{3}$ $2.2 \%$ であり, それ以外の 組成は他の 飼料とほぼ 同様である。また動物には脱イオン水を自由攝取 させた。 4 週間の飼育後，エーテル麻酔下です心゙ てのラットの左頸動脈から採血を行なった。つ、 で血液を遠心分離（3000rpm） し，血清を得て， それに含まれる無機および有機成分の 定量を行な った。

1）無機成分の定量

$\mathrm{Ca}, \mathrm{Sr}, \mathrm{Mg}$ などについては $0.2 \mathrm{ml}$ の血清を用 い,これをWasserman らの方法 ${ }^{12} に よ り$ 処理し たのち, 原子吸光分光光度計 (パーキンェルマ社 製503型)を用いて定量した。また，Pについては， $0.2 \mathrm{ml}$ の血清を用い， Eastoe の方法 ${ }^{14)}$ により定 量した。

2）有機成分の定量

総 Hexosamine： 血清 $0.02 \mathrm{ml}$ に $1 \mathrm{ml}$ の $4 \mathrm{~N}$

Serum contents of inorganic and organic substances in the rat given strontium carbonate.

Akira MAтsumoto (Department of Pharmacology, School of Dental Medicine, Tsurumi University, Yokohama)

* 神奈川県横浜市鶴見区鶴見 2-1-3（勇 230） Jap. J. oral Biol., $18:$ 324-328, 1976. 
$\mathrm{HCl}$ を加えて封管後, $100^{\circ} \mathrm{C}$ で 4 時間加水分解し た。この水解物について Belcher らの方法 ${ }^{15)}$ を用 いて測定した。

Hydroxyproline : 血清 $1 \mathrm{ml} に$ Conc. $\mathrm{HCl} 1$ $\mathrm{ml}$ を加え封管後, $100^{\circ} \mathrm{C} て ゙$ 48時間加水分解した。 この水解物について Prockop \& Udenfriend の 方法 ${ }^{16)}$ を用いて測定した。

\section{結 果}

1）血清中の無機成分

図 1 は血清中の $\mathrm{Ca}$ の含有率を示しせものであ ろ。 $\mathrm{Sr}$ 群と $\mathrm{Sr}-\mathrm{Ca}$ 群において， Ca の含有率は 対照群よりも有意の減少を示した $(\mathrm{P}<0.01-$ 0.001)。また, 減少の程度については, Sr 群に おいて Sr-Ca 群よりも著明であった。対照群と 低 $\mathrm{Ca}$ 群との間には有意差は認められなかった。

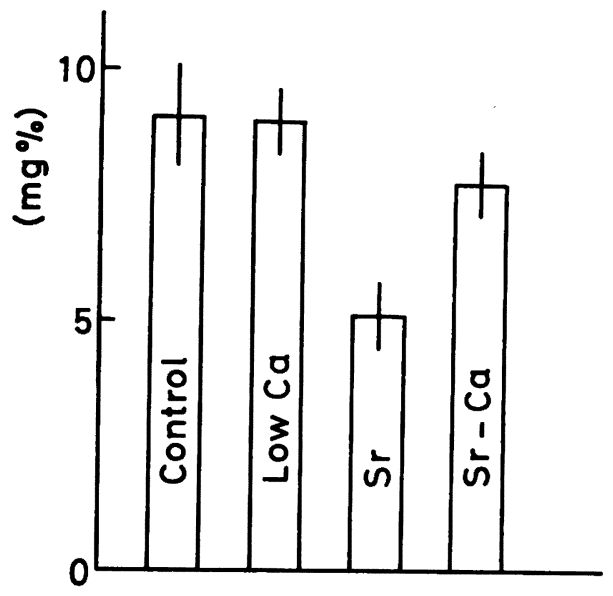

図 1 血清中の $\mathrm{Ca}$ 含有率

各々のヒストグラムは平均值と標準偏差を示 したものである。

Control, 対照群; Low $\mathrm{Ca}$, 低 $\mathrm{Ca}$ 群; $\mathrm{Sr}$,

$\mathrm{Sr}$ 群; $\mathrm{Sr}-\mathrm{Ca}, \mathrm{Sr}-\mathrm{Ca}$ 群を示す。

図 2 は血清中の $\mathrm{P}$ の含有率を示したものであ る。Pの含有率は低 $\mathrm{Ca}$ 群, $\mathrm{Sr}$ 群, $\mathrm{Sr}-\mathrm{Ca}$ 群に おいて対照群とくらべ有意の増加を示した（P< 0.01)。しかし, 低 $\mathrm{Ca}$ 群, $\mathrm{Sr}$ 群ならびに SrCa 群間においては有意差は認められなかった。

図 3 は血清中の $\mathrm{Sr}$ の含有率を示したものであ る。 $\mathrm{Sr}$ の含有率は $\mathrm{Sr}$ 群において $\mathrm{Sr}-\mathrm{Ca}$ 群より も高い値を示した（P<0.001）。また対照群と低

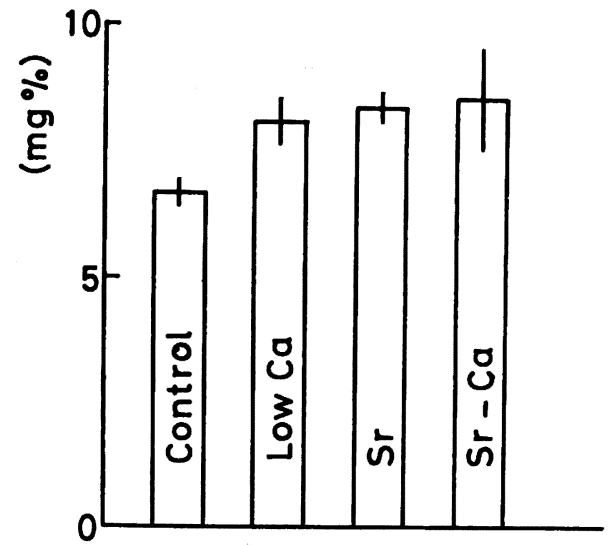

図 2 血清中の $\mathrm{P}$ 含有率

各々のヒストグラムは平均値と標準偏差を示 したものである。

Control, 対照群; Low $\mathrm{Ca}$, 低 $\mathrm{Ca}$ 群; $\mathrm{Sr}$, $\mathrm{Sr}$ 群; $\mathrm{Sr}-\mathrm{Ca}, \mathrm{Sr}-\mathrm{Ca}$ 群を示す。

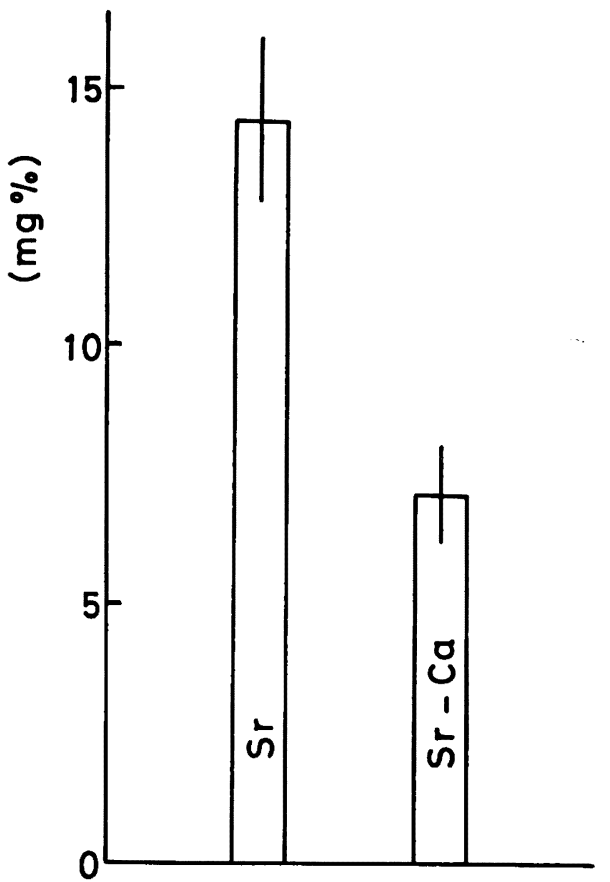

図 3 血清中の $\mathrm{Sr}$ 含有率

各々のヒストグラムは平均值と標準偏差を示 したものである。

$\mathrm{Sr}, \mathrm{Sr}$ 群; $\mathrm{Sr}-\mathrm{Ca}, \mathrm{Sr}-\mathrm{Ca}$ 群を示す。

$\mathrm{Ca}$ 群の血清中には, Sr は検出できなかった。

図 4 は血清中の $\mathrm{Mg}$ の含有量を示したもので ある。 $\mathrm{Mg}$ の含有率は $\mathrm{Sr}$ 群ならびに $\mathrm{Sr}-\mathrm{Ca}$ 群 において対照群とくらべ有意の減少を示した（P 


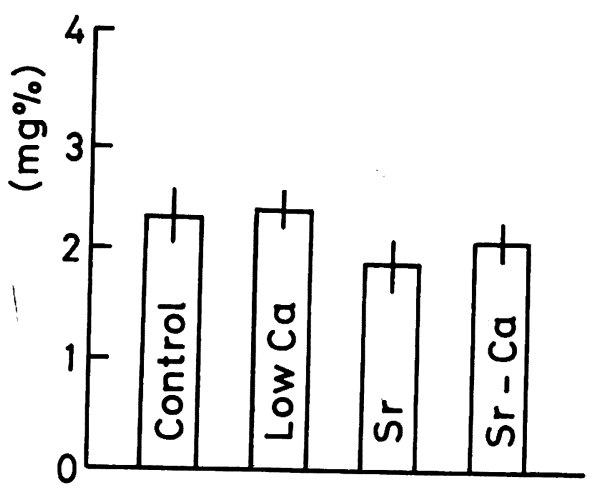

図 4 血清中の $\mathrm{Mg}$ 含有率

各々のヒストグラムは平均值と標準偏差を示 したものである。

Control, 対照群; Low $\mathrm{Ca}$, 低 $\mathrm{Ca}$ 群 ; $\mathrm{Sr}$,

$\mathrm{Sr}$ 群; $\mathrm{Sr}-\mathrm{Ca}, \mathrm{Sr}-\mathrm{Ca}$ 群を示す。

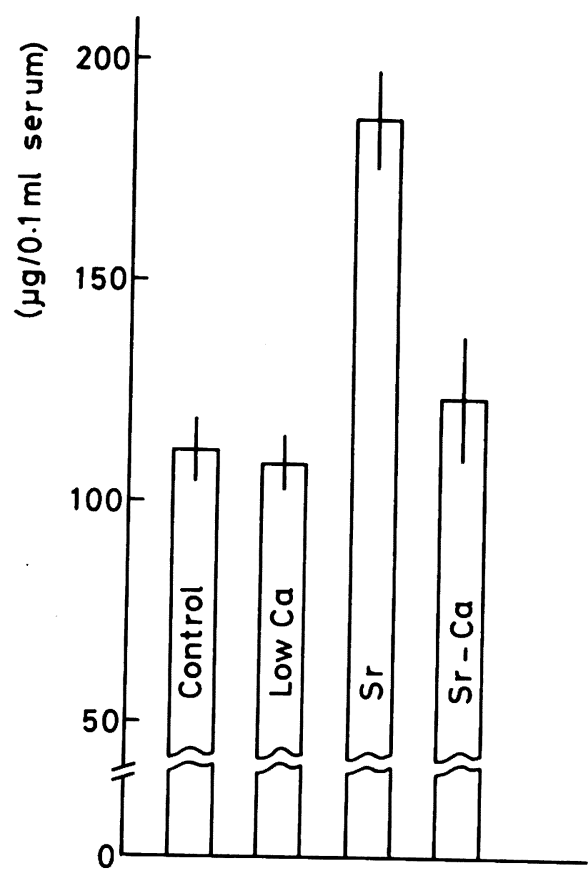

図 5 血清 $0.1 \mathrm{ml}$ 中の総へキソサミン含有量 各々のヒストグラムは平均值と標準偏差を示 したものである。

Cotronl, 対照群; Low $\mathrm{Ca}$, 低 $\mathrm{Ca}$ 群 ; $\mathrm{Sr}$, $\mathrm{Sr}$ 群 ; Sr-Cr, Sr-Ca 群を示す。

<0.01)。また対照群と低 $\mathrm{Ca}$ 群との間には有意 差は認められなかった。

2）血清中の有機成分

図 5 は血清中の総へキソサミン量を示したもの である。血清0.1ml 中の総へキソサミンの含有量

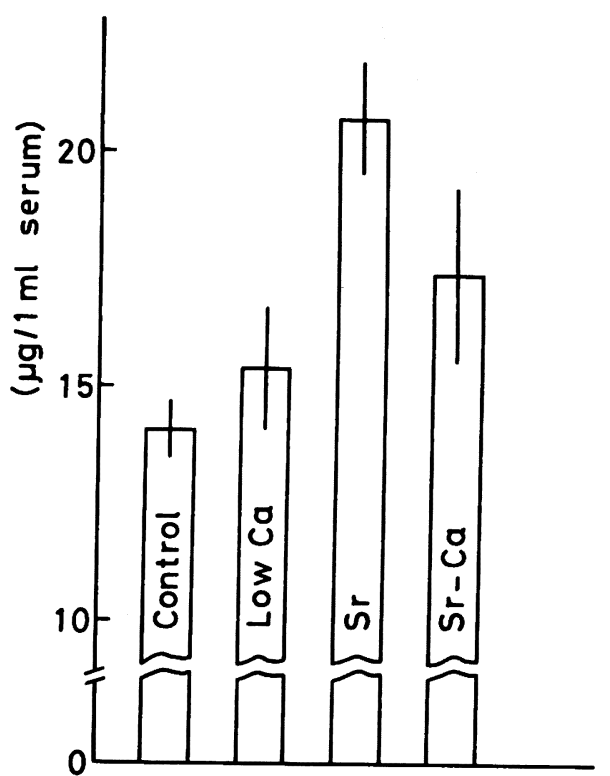

図 6 血清 $1 \mathrm{ml}$ 中のハイドロキシプロリン含有量 各々のヒストグラムは平均值と標準偏差を示 したものである。

Control, 対照群; Low $\mathrm{Ca}$, 低 $\mathrm{Ca}$ 群 ; Sr, $\mathrm{Sr}$ 群 ; Sr-Ca, Sr-Ca 群を示す。

は，Sr 群ならびに Sr-Ca 群において対照群とく らべ有意の増加を示した（P<0.01-0.001）。 Sr 群における総へキソサミン含有量の増加は, Sr$\mathrm{Ca}$ 群よりも著明であった。また対照群と低 $\mathrm{Ca}$ 群との間には有意差は認められなかった。

図 6 は血清中のハイドロキシプロリン量を示し たものである。血清 $1 \mathrm{ml}$ 中のハイドロキシプロ リンの含有量は低 $\mathrm{Ca}$ 群, $\mathrm{Sr}$ 群, $\mathrm{Sr}-\mathrm{Ca}$ 群にお いて対照群とくらべ，いずれも有意の増加を示し た $(\mathrm{P}<0.05-0.001) 。$ 。 $\mathrm{Sr}$ 群におけるハイ ドロキシプロリン含有量の増加は，総へキンサミ ンの場合と同様に著明であった。

\section{考 察}

我々は前報において ${ }^{81}$, 炭酸ストロンチウム投 与ラット脛骨において， Ca, P などの無機成分が 減少すること，およびガラクトサミン，グルコサ ミン，ハイドロキシプロリンなどの 有機成分が増 加することを報告した。

本実験においては，Sr 投与ラットにおける 血 清中の $\mathrm{Ca}, \mathrm{P}, \mathrm{Sr}, \mathrm{Mg}$ などの 無機成分の含有量 
を調べた結果, $\mathrm{Ca}$ の減少, $\mathrm{P}$ の増加, $\mathrm{Sr}$ の増加, $\mathrm{Mg}$ の減少が認められ，また血中総へキソサミン およびハイドロキシプロリンの増加を認めた。

$\mathrm{Sr}$ 投与により血中の $\mathrm{Ca}$ 量が低下することは すでに報告されている ${ }^{9,10,12,17)}$ 。このことは，硬 組織石灰化障害を生ずる要因の一つと考えられよ う。 $\mathrm{Sr}$ 投与による血中 $\mathrm{Ca}$ 量の低下は，ビタミ ンDの腎臟における活性化阻害 ${ }^{18,19)}$ に伴う腸管に おける $\mathrm{Ca}$ の吸収阻害 ${ }^{5,12)}$ ，などによるものかも しれない。

$\mathrm{Sr}$ 投与による血清中の 無機燐の 増量の 原因の 一つとしては，腎における排泄障害が考えられる かもしれない。

血中 $\mathrm{Sr}$ 量の定量結果についてはすでに 報告が なされている9”。 Sr-Ca 群に打ける血清中の $\mathrm{Sr}$ 值は, $\mathrm{Sr}$ 単独投与群にくらべ小さな值を示した こと（図 3 ）から， Ca を投与することにより， Sr による障害が減弱するものと考えられよう。

$\mathrm{Sr}$ 投与による血中 $\mathrm{Mg}$ 量の 減少については, これまで報告されていないように思われる。この 事柄についての意義は，現在のところ不明であ る。

$\mathrm{Sr}$ 投与ラットに打ける血中総へキソサミンお よびハイドロキシプリンの増量についても，これ まで報告はなされていないように思われる。 $\mathrm{Sr}$ 投与により，骨や歯などの結合組織における多糖 類の代謝拉よびュラーゲン代謝に何等かの 異常が 生じたり，腎臟における機能障害などが生じ，そ れらの総合的結果として, 血中の総ヘキソサミン およびハイドロキシプロリンが増加したものと考 えられるが, その機序の詳細については, 現在の ところ不明である。

稿を終るにあたり，想篤なご指導ならびにご校閲を賜 わった千葉元永教授に 媣謝する。また諭文の校正に際 しここ助力いただいた大岡公子助手ならびに実験にあた ってご協力下さった荻原清久氏に感謝する。

\section{文献}

1) Stoelzner, H.: Über den Einfluß von Strontiumverfütterung auf die chemische Zusammensetzung des wachsenden Knochens. Biochem. Z., 12 : 119-137, 1908.

2) LeHNERDT, F. : Zur Frage der Substitution des Calciums im Knochensystem durch Stron- tium. II. Mitteilung. Strontiumfütterung an säugende Tiere, der Einfluß des Strontiums auf das Knochensystem der gesäugten Jungen Beitr. pathol. Anat. allg. Pathol., $47: 215-247,1910$.

3) Shipley, P. F. and PARK, E. A.: Studies on experimental rickets. XX. The effects of strontium administration on the histological structure of the growing bones. Jhons Hopk. Hosp. Bull., 33 : 216-220, 1922.

4) Klein, H., Becker, J. E. and McCollum, E. V.: The effects of strontium administration on the histological structure of the teeth of rats. J. dent. Res., $10: 733-738$, 1930.

5) ENGFeldT, B., Hiertquist, S. and LAGERGREN, C.: The effect of strontium intake on rats maintained on a very low calcium diet. Acta Soc. Med. Uppsal., $67: 239-257$, 1962.

6）姥山良雄: $\mathrm{SrCl}_{2}$ 投与ラットの切歯にみられる 石灰化不全象牙質について. 口病誌, $31: 225-$ 238, 1964.

7）松本章：炭酸ストロンチウム投与ラットの脛骨 骨端の発育障害と骨端軟骨基質中の多糖類の消 長ならびにこれに対する papain の抑制効果. 口病誌, 36 : 108-120, 1969.

8）松本章：炭酸ストロンチウム投与ラットの脛骨 骨幹部における無機および有機成分の含有量に ついて. 歯基礎誌, $18: 319-323,1976$.

9) StOREy, E. : Strontium "rickets": Bone, calcium and strontium changes. Aust. Ann. Med., 10 : 213-222, 1961.

10) STOREY, E. : Calcium and strontium changes in bone associated with continuous administration of stable strontium to rats. Arch. Biochem. Biophys., 103 : 575-581, 1968.

11) Engfeldt, B. and Hjertouist, S.: The effect of strontium administration on bones and teeth of rats maintained on diets with different calcium contents. Virchows Arch. Abt. A Path. Anat., $346:$ 330-344, 1969.

12) Corradino, R. A., Ebel, J. G., Craig, P. H., TAYLOR, A. N. and WASSERMAN, R. H. : Calcium absorption and the vitamin $\mathrm{D}_{3}$-dependent calcium-binding protein. I. Inhibition by dietary strontium. Calc. Tiss. Res., $7:$ :81-92, 1971.

13) Matsumoto, A.: Sudanophil material at the sites of calcification in dentine, bone and epiphyseal cartilage plate in the rat given strontium carbonate. Tsurumi Univ. dent. J., $1: 21-28,1975$.

14) EAstoe, J. E.: Methods for the determination of phosphate, calcium and protein in small portions of mineralised tissues. Calc- 
ified Tissue (edited by Richelle, L. J. and Dallemagne, M. J.), 265-274, Universitè Liegè, Liegè, 1965.

15) Belcher, R., Nutten, A. J. and SAmbrOOK, C. M. : The determination of glucosamine. Analyst, 79 : 201-208, 1954.

16) PROCKop, D. J. and UdENFRIEND, S. : A specific method for the analysis of hydroxyproline in tissue and urine. Anal. Biochem., 1 : 228-239, 1960.

17) Corradino, R. A., Ebel, J. G., Craig, P. H., TAYLOR, A. N. and WASSERMAN,
R. H. : Calcium absorption and the vitamin $\mathrm{D}_{3}$-dependent calcium-binding protein. II. Recovery from dietary strontium inhibition. Calc. Tiss. Res., $7:$ 93-102, 1971.

18) DeLuCA, H. F.: Metabolism and mechanism of action of 25-hydroxycholecalciferol. Cellular Mechanisms for Calcium Transfer and Homeostasis (edited by Nichols, G. and Wasserman, R. H.), 421-440, Academic Press, New York and London, 1971.

19）須田立雄：ビタミンDの代謝異常と骨軟化症. 骨代謝，9:367-373， 1976. 